\title{
Contour Ridge Tillage for Improved Crops and Fodder Trees Production in the Villages of Kani and Noumpinesso, Southern- Mali
}

Cheick Oumar Dembele (Corresponding Author)

Research assistant at Institute of Rural Economy /Regional Centre of Applied Research of Sotuba BP: 258 Bamako; PhD student at University of Sciences, Technics and Technologies (USTTB) of Bamako Mali

\section{Kalifa Traore}

$\mathrm{PhD}$, Senior Researcher, Agronomist, Soil Scientist at Institute of Rural Economy /Regional Centre of Agronomic Research of Sotuba BP: 258 Bamako

\section{Moussa Karembe}

Professor at University of Sciences, Technics and Technologies of Bamako Mali

\section{Birhanu Zemadim}

$\mathrm{PhD}$, Senior Researcher, Coordinator of Africa Research In Sustainable Intensification for the Next Generation (Africa RISING) of Mali, International Crops Research Institute for the Semi-Arid Tropics (ICRISAT)

Fotigui Cisse, Oumar Samake

Research assistants at Institute of Rural Economy /Regional Centre of Agronomic Research of Sotuba BP: 258 Bamako

Received: April 10, 2021 Accepted: May 11, $2021 \quad$ Published:June 10,2021

doi:10.5296/jas.v9i2.18513

URL: https://doi.org/10.5296/jas.v9i2.18513

\begin{abstract}
In rural Mali shortage of livestock feed is a challenging phenomenon worsening day by day, particularly in the villages of Kani and Noumpinesso. The significant decrease in crops yield and
\end{abstract}


livestock are due to persistent and continuous land degradation and over grazing. Soil water erosion and inappropriate or ineffective farming systems led to land degradation over the many years. A purposeful growing of fodder plant (fast growing trees species) and crops in interacting combinations for a range of benefits would be required using a technology that is easily adaptable by the rural farming communities. Contour ridge (CR) technology is a holistic approach that protects farmlands from erosion; increases soil moisture, nutrient availability for crops and associated fast growing trees. The CR technology in combination with forage and improved crop production systems were applied in Kani and Noumpinesso villages of southern Mali and resulted indicated that at the end of rainy season of 2017 and 2018 the application of CR technology significantly increased $(\mathrm{p}<0.05)$ Gliricidia sepium and Leucaena leucocephala growth and development. Similar to 2017, in 2018 CR technology significantly increased ( $\mathrm{p}<$ 0.05) sorghum, millet, maize, and cotton growth, yield, and economic benefit. At Kani during 2017 and 2018 season soil moisture was always significantly higher $(\mathrm{p}<0.05)$ under fodder planted area than non-fodder planted area, and the difference was high with respect to farmlands without CR.

Keywords: fodder plant, crops, contour ridge, and soil moisture

\section{Introduction}

Practicing a combination of trees and crops in the rural farming technique is a useful system to manage agricultural resources (land, water and trees) and benefit from the ecosystem services of the combinations. In Kani and Noumpinesso several trees (Vitellaria paradoxa, Parkia biglobosa, Adansonia digitata, Tamarindus indica etc.) were naturally left to grow along with crops in farmers' field. While this is an appropriate farming practice in rural Mali, it is essentially important for watershed management efforts that combine different approaches and reduce the impact of unsustainable agricultural practices on land degradation. In the rural Malian farming community context, land is what the farmer owns and be prepared to conserve over longer period of time. However, efforts have been limited to keep the health of the land in most rural community thus land degradation has become a threat for agricultural productivity improvement and ecosystem services. Herbold (2003) reports that the role of trees in smallholder farms include provision of: fruits, nuts, edible leaves and other food sources. The presence of trees in farm lands is also beneficial as a shed; land conservation, especially when trees are planted on hills and reservoirs and improving soil fertility. In the hot and dry semiarid tropics crops grow better under trees. The presence of tree shade lowers soil surface temperature; tree roots act like hydraulic pumps and hence bring water from a depth below 20 meters deep, creating water available for crops during drought periods (Ortolani, 2017). In addition to improving crop yields, fodder and timber, the trees associated with crops in farm fields retain many environmental benefits and ecosystem services like erosion control, soil fertility, water availability, habitat and species diversity, and improved aesthetics in agricultural landscapes (Jose, 2009). Trees associated with crops in farmers' field offer multiple benefits, including the protection of crops from extreme heat and water loss, and prevention of farm runoff (De et al., 2007). In the farm, trees develop deeper root systems; protect soil to drought and strong winds. Trees also preserve groundwater quality by limiting water-pollution caused by nitrate leaching and help decrease 
water runoff by improving water infiltration in soil. They store carbon in their wood and in the soil of which crops profit to increase their growth and yield. Generally, the overall biomass productivity is improved with the presence of more trees in farmlands, which further improves soil fertility (Palsaniya, 2012). Implementation of CR technology with leguminous trees will introduce atmospheric nitrogen in the soil and further improve soil moisture and nutrient availability for crops and trees growth. The success of CR technology is widely acknowledged in multiple reports (Gigou et al., 2006; Traore et al., 2006; Doumbia et al., 2012, Birhanu et al., 2020; Traore et al., 2020). Farmers in Kani and Noumpinesso villages adopted CR technology that helped to reduce the speed of runoff allowing infiltration into the farm fields. Traoré et al. (2002) summarized the expected benefits of CR technology on soil quality to include the following: (1) reduce soil erosion and biodiversity, (2) increased growth of trees and plants, especially those that destroy leaves every year, (3) increase yields due to increased soil moisture, and (4) fodder and building materials from perennial grasses to stabilize main ridges and runoff. Our activities in the studied villages were linked to agronomy through cereals and cotton production-based farming systems improvement; livestock, agroforestry and mitigation (climate change) through fast growing fodder tree species. In Kani and Noumpinesso villages soil degradation is the main constraint for crops productivity and fodder. Kouyate (2000) reported that in Mali low crop productivity is due to land degradation. Shepherds in these villages spent 6 to 8 months in transhumance to feed their animals in different locations. There has been no policy yet to resolve this transhumance practices that bring conflict with the farming community. Introducing fast growing tree species in many of the farm lands for fodder will contribute to increase availability of animal feed, reduce rural migration, and to improve household energy need. The main objective of this study was to evaluate the improvements in crops yield, forage biomass and tree growth parameters through the application of CR technology associated with fast growing tree species and cropping system in farmers' field. The specific objectives were: (I) evaluating the effect of CR technology on growth and development of fodder legumes trees species; (II) determining the impact of CR technology on crops growth and yield and (III) evaluating the effect of combination of CR technology and trees on soil moisture.

\section{Materials and Methods}

\subsection{Site Descriptions}

The study was conducted at Kani and Noumpinesso (Figure 1), two neighboring villages of 5 $\mathrm{km}$. The village of Kani is located $45 \mathrm{~km}$ from Koutiala in the rural district of Nafanga (Karangasso), Koutiala region. It is distant from the national road (RN12) of $5 \mathrm{~km}$. Kani is situated at Latitude $12^{\circ} 14^{\prime} 43.23^{\prime \prime}$ North and longitude $5^{\circ} 10^{\prime} 57.94 "$ West with an elevation of $384 \mathrm{~m}$ in Koutiala district, which makes it a Sudanese zone. The essential characteristic is the alternation of a long dry season from November to March and a rainy season from May to October. Most of this amount of rain is eroded in the watershed through Noumpinesso. 


\section{Macrothink}

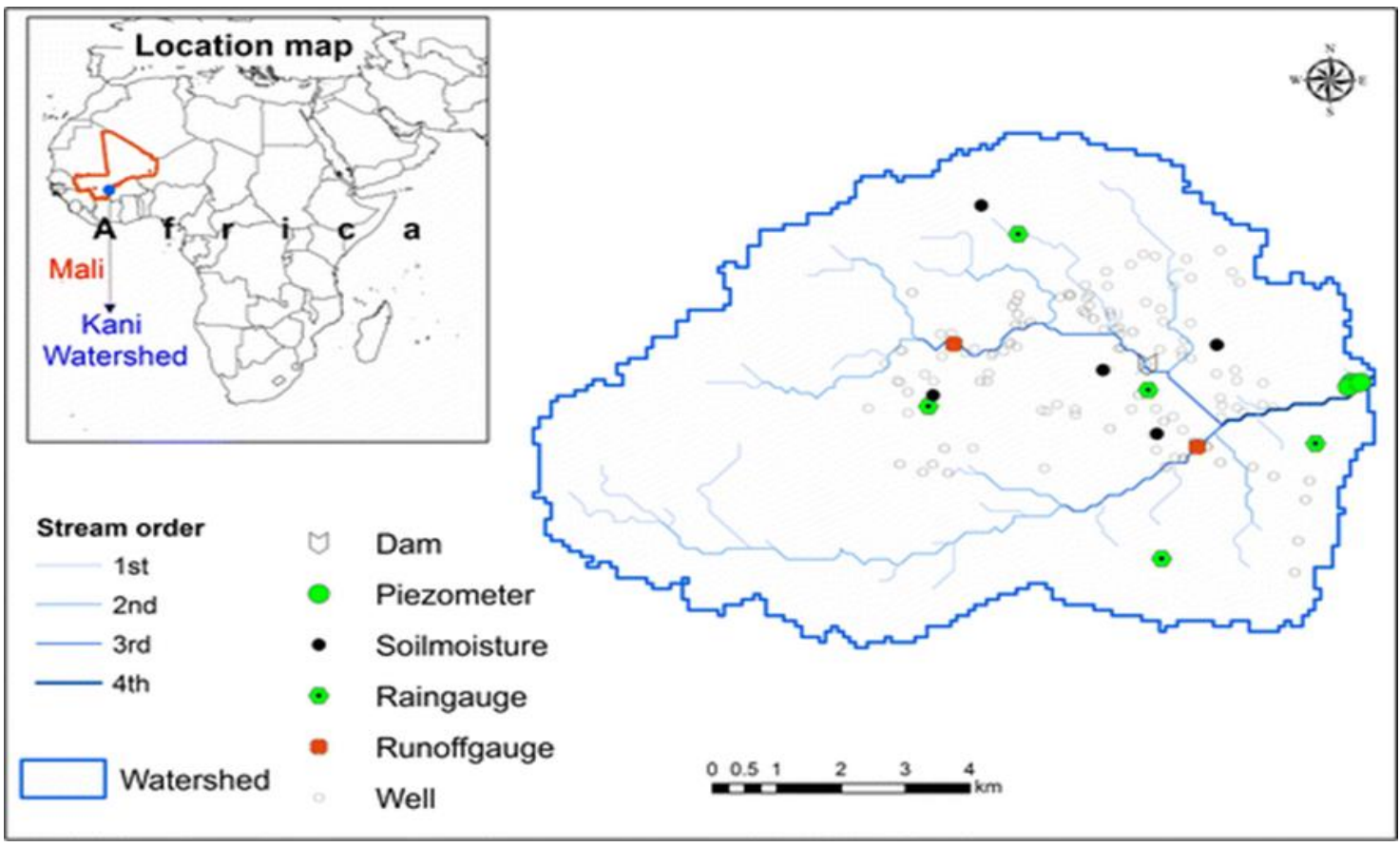

Figure 1. Location of Kani watershed in southern Mali (Koutiala district) (Birhanu et al, 2018)

The population of Kani and Noumpinesso depends on agriculture and livestock. Their main activities are the culture of sorghum, cotton, millet, maize etc. Kani and Noumpinesso present a relief dominated by basins and plateaus. Soils of these villages are gravel spreader type and silt-sand. They are leached and hydro morphs. Dominant soil types in the two villages are classified as leached tropical ferruginous soils with spots and at gley in deep. The relief is characterized as a whole by armored plateaus and some basins. Vegetation cover is poor and supplied some large trees, shrubs and various grasses of medium size. It is characterized as a whole by a vegetation of the type of woody savanna at strong degradation caused by overexploitation, overgrazing and erosion. The following species are: found Baobab (Adansonia digitata), Shea tree (Vitellaria paradoxa), Nere (Parkia biglobosa), Tamarind (Tamarindus indica), Wild date (Balanites aegytiaca). The herbaceous vegetation consists essentially of: Pennisetum padicelatum, Digitaria exils. Annual rainfall varied from 800 to $1100 \mathrm{~mm}$. Figure 2 show that in 2017 annual rainfall was $1072 \mathrm{~mm}$ and $1005 \mathrm{~mm}$ in 2018. The maximal rainfall of $285 \mathrm{~mm}$ was observed in July in 2017 and $382 \mathrm{~mm}$ in August in 2018. 


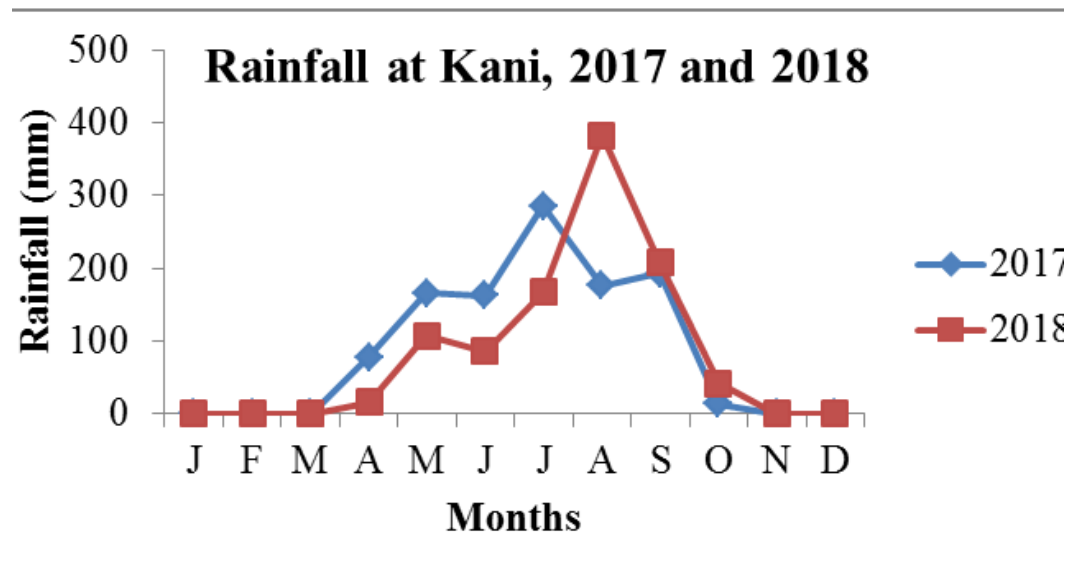

Figure 2. Rainfall situation at Kani in 2017 and 2018

\subsection{Contour Ridge Installation}

For CR installation the topographic level and a graduated rule were used to determine and materialize contour line by staking at a regular distance. A field visit with each farmer or diagnosis allowed us to identify water circulation routes and the problems of erosion or flooding that occurred, fields made in CRT technology varied from one (1) to three (3) ha by farmer. The implementation of contour line started at $25 \mathrm{~m}$ away from the upstream limit of field. On the contour lines, stakes were placed every ten (10) meters for the materialization, 3 or 4 round trip of an oxen plow was done to make an earth bund of $1 \mathrm{~m}$ wide called "Distance between main or permanent ridges was fifty (50) meters. Rows of seedlings or ridges were parallels to main ridge for a good functioning of the arrangement and the main ridges (ados) were reinforced by hoes. Spontaneous grasses were usually allowed to grow on some main ridges and fodder plants were planted at the crest of two main ridges in each field. Annual crops (cotton, maize, sorghum, and millet) and fodder plants (Gliricidia sepium and Leucaena leucocephala) were grown together in the same field, similarly in CRT and NCR plots in 2017 and 2018. All field operations also, were done at the same period and manner. Implementation of CR includes 4 steps (Gigou, 2006; Traore, 2004; Traore 2020):

Step 1: Diagnosis of the water management constraints to identify specific run-on and excessive run-off conditions and the need for waterways, and special water management structures required for the specific field.

Step 2: Staking the permanent ridges requires planning and locating the number and distance between the permanent ridges. The maximum spacing of the permanent ridges is $50 \mathrm{~m}$ and the maximum elevation change between permanent ridges is $1 \mathrm{~m}$. The permanent ridges are positioned perpendicular to the slope and capture the small rains but diverts the most intense. Permanent ridges achieve maximum efficiency of water capture and retention in crop and tree root zone.

Step 3: Ridges or crop rows should follow permanent ridges and proceed upslope to 
maximize rainfall capture and retention.

Step 4: At the first-year maintenance operations are usually needed after heavy rains breeching permanent ridges. At the beginning of rainy season, annual maintenance of reinforcing permanent ridges is needed. Permanent ridges are solid and stable after one year, which can be planting with grasses and trees such as Andropogon gayanus, Gliricidia sepium, Leucoena leucocephala, etc. Those produce forage, cooking and building materials.

\subsection{Plantation of Fodder Plants in the Fields}

Fodder plants were initially raised in the nursery; three thousand one hundred and sixty-nine (3169) pots were filled with earth mixed with $1 / 4$ of manure. Seeds of Leucaena leucocephala were soaked in boiling water for two (2) days and those of Gliricidia Sepium in no boiling water for two (2) days as well. Seedling was done on 28/03/2017 at the rate of one grain per pot. Nursery was watered two (2) times daily (morning and evening) and treated with forbidden 5G every fifteen (15) days from 07/04/2017 and four (4) times before transplantation. Re-seedling was done fifteen (15) days after seedling and plants were transplanted by motorcycles in wooden crates from 15 to 20/07/2017 and planted in the crest of the ridges in CR and NCR plots. Plants were planted in seed hole of $20 \mathrm{~cm}$ diameter and $30 \mathrm{~cm}$ deep in which 60 to 80 seedlings were planted in 40 fields, each one being a replication. At the end of the rainy season, plants were traditionally protected from open grazing. In 2018 fodder plans were more developed and reached about $2 \mathrm{~m}$ height, and in 2017 the same plants were less than $1 \mathrm{~m}$ high. To assess growth and development of fodder plant, height, diameter at base, and crown radius were determined each 15 days in 10 replications. At each year, the last data of November of the 10 replications was statistically analyzed for Gliricidia Sepium and Leucaena leucocephala. Couple design was used as experimental design in which two neighboring plots (CR plot and NCR plot) were planted in trees. For each replication 10 trees were chosen in CR plots and NCR plots to determine fodder trees growth. Two trees were chosen in each plot to determine biomass yield.

\subsection{Monitoring of Soil Moisture}

Moisture measurements were performed using a time domain reflectometry (TDR) probe at an interval of 10 days. Measurements were made in CR and NCR plots (under and outside plants) and displayed directly in volumetric moisture. For the principle, access tubes were installed in CR plots and NCR plots fields. To take data the Profile Probe (PR2) is inserted in the tubes. Data is read on Hand Held (HH2) moisture meter connected to PR2 Profile Probe by cable. Data stored in $\mathrm{HH} 2$ moisture meter are transferred to computers. The HH2 is a unit of read versatile, it allows an easy and convenient way to display and store data in Profile Probes. The manufacturer is Delta-T Devices.

\subsection{Contour Ridge Evaluation on Crops Production}

Data was taken in 40 fields (replications), for the two years of research we took data in CR plot and NCR plot for each replication on different crops (cotton, maize, sorghum, and millet) growth and yield. Experimental design was couple design as crops were seedling in two neighboring plots (CR plot and NCR plot) for each replication. Five yield squares were 


\section{Macrothink

placed in each plot to take data. For the 40 replications crop used depended on the owner of farm for each replication. Crops used were sorghum, millet, cotton and maize.

\subsection{Determination of Value to Cost Ratio (VCR)}

Input costs and crop peak prices were used to calculate VCR as a first indicator of acceptability of investment, using the formula of Nziguheba et al. (2010): VCR $=(Y-Y c) / X$

Where $\mathrm{Y}$ is the value of the crop in intervention plots, $\mathrm{Yc}$ is the value of the crop harvested in control plots, and $\mathrm{X}$ is the cost of inputs (seeds, fertilizers, pesticide and $\mathrm{CB}$ cost).

\subsection{Statistical Analysis}

Data was subjected to analysis of variance using GENSTAT version 12 (GenStat Release 12.1 (PC/Windows Vista) Copyright (2009), VSN International Ltd) and significant means were separated with least significant difference (Lsd) at $5 \%$. Some data was analyzed using the EXCEL software for intermediate calculations and graphic.

\section{Results and Discussion}

\subsection{Effect of CR Technology on Fodder Plants Growth and Development}

From the beginning to the end of rainy season, growth and development of fodder plant were progressively increased. Fodder plants were more developed in CR plots than in the NCR (Figure 3.4.5 and 6). 


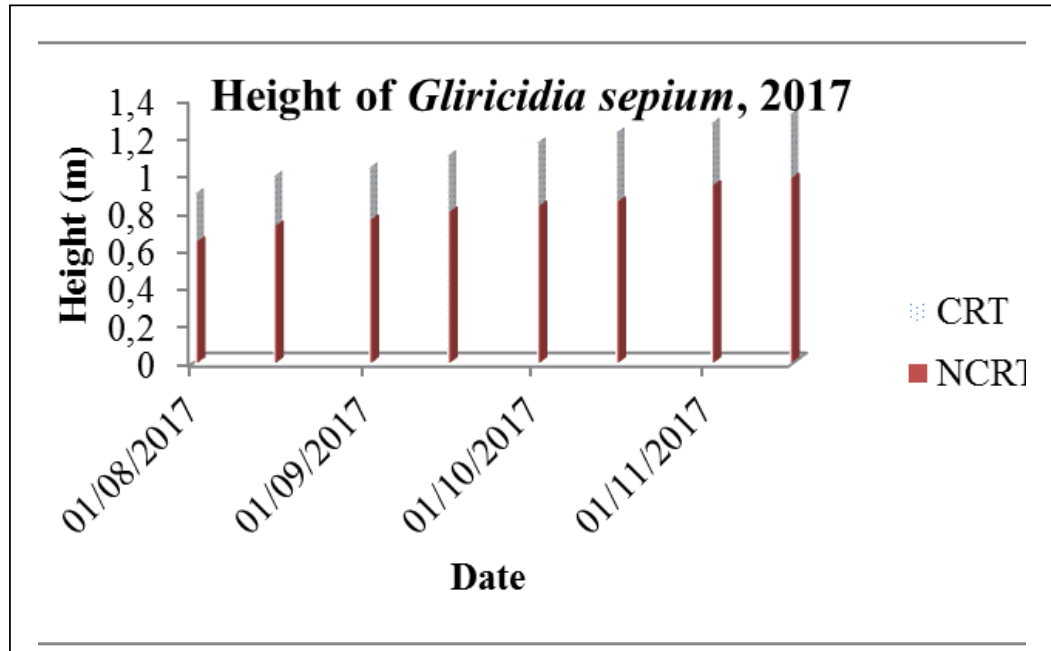

14Basal diameter of Gliricidia sepium, 2017

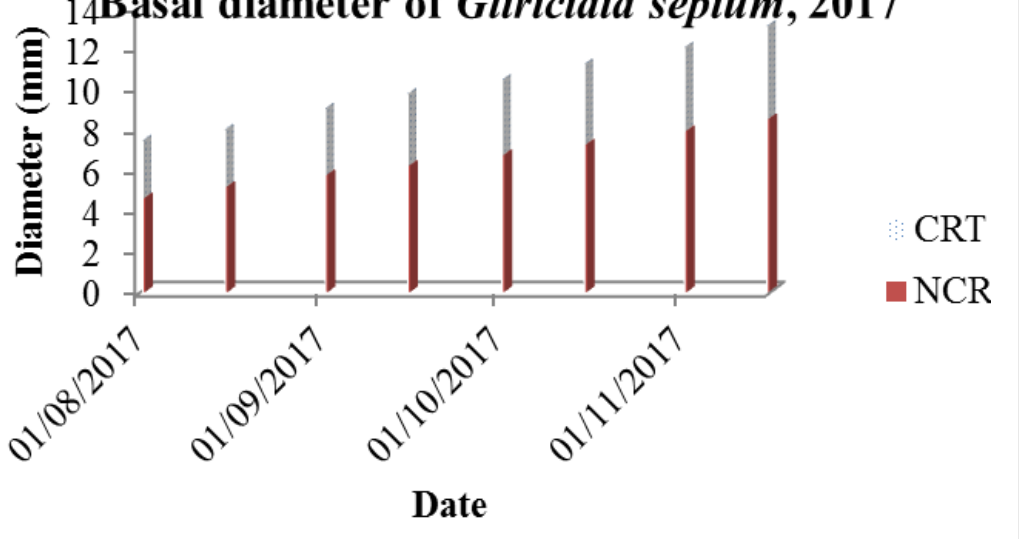

@ 0,5 Crown radius of Gliricidia sepium, 2017

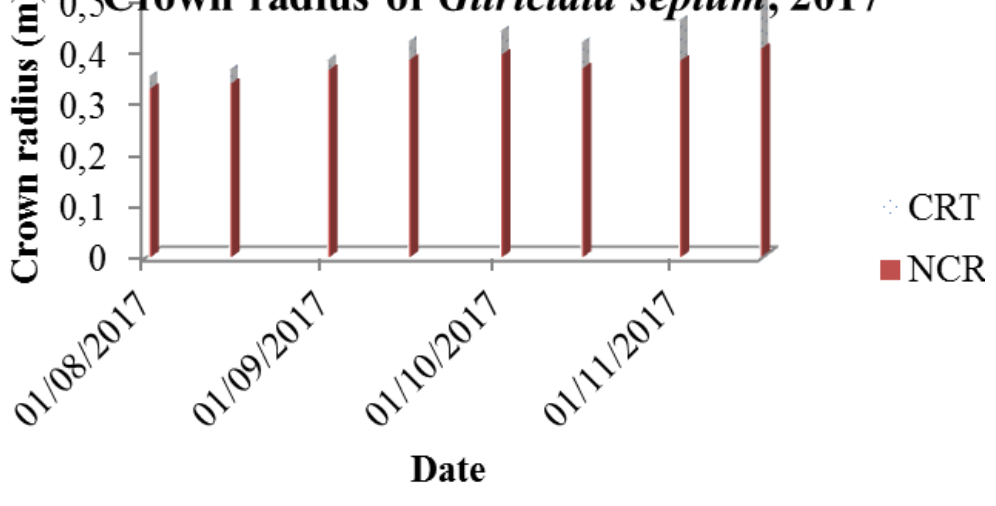

Figure 3. Effect of contour ridge technology (CRT) on Gliricidia sepium growth and development at Kani and Noumpinesso, 2017 


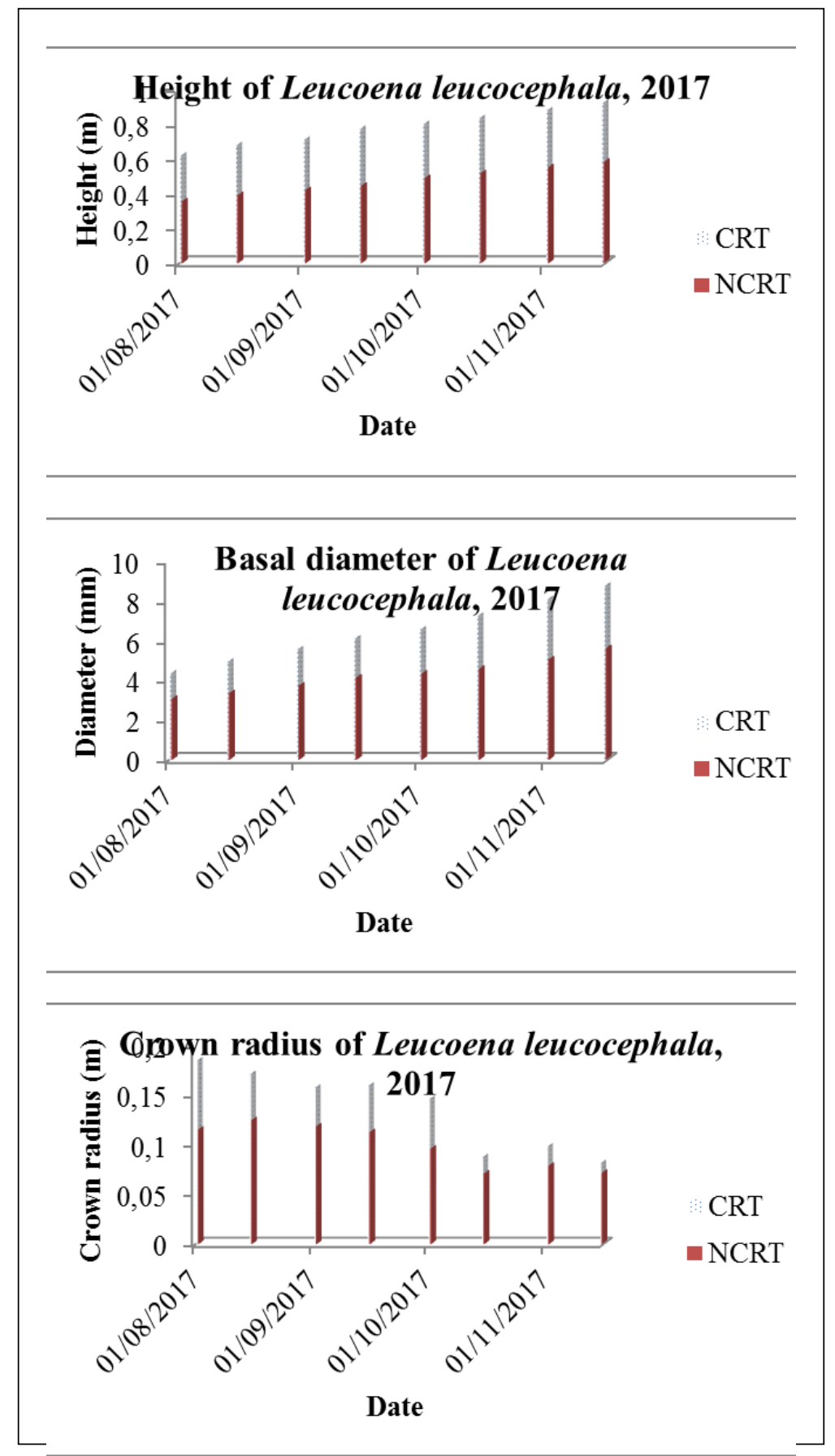

Figure 4. Effect of CRT on Leucaena leucocephala growth and development at Kani and Noumpinesso, 2017 

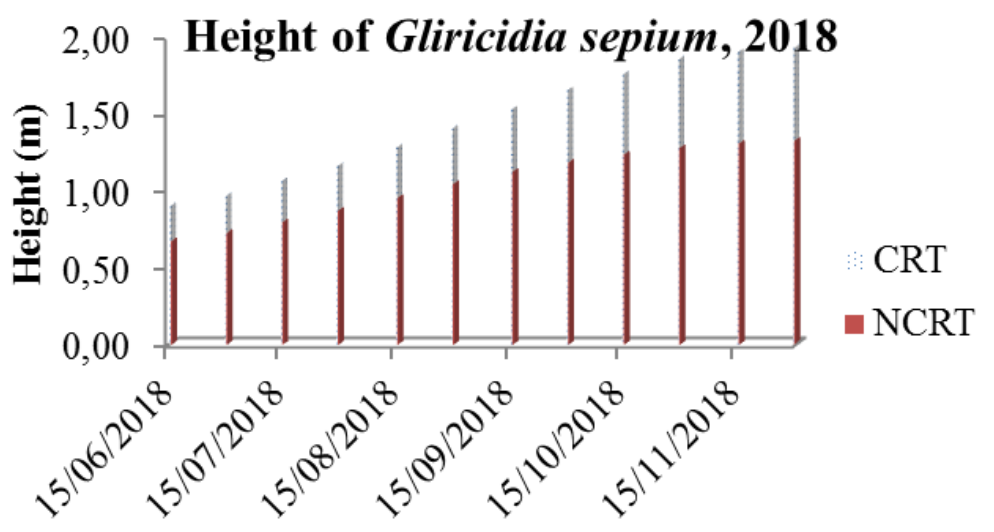

\section{Date}

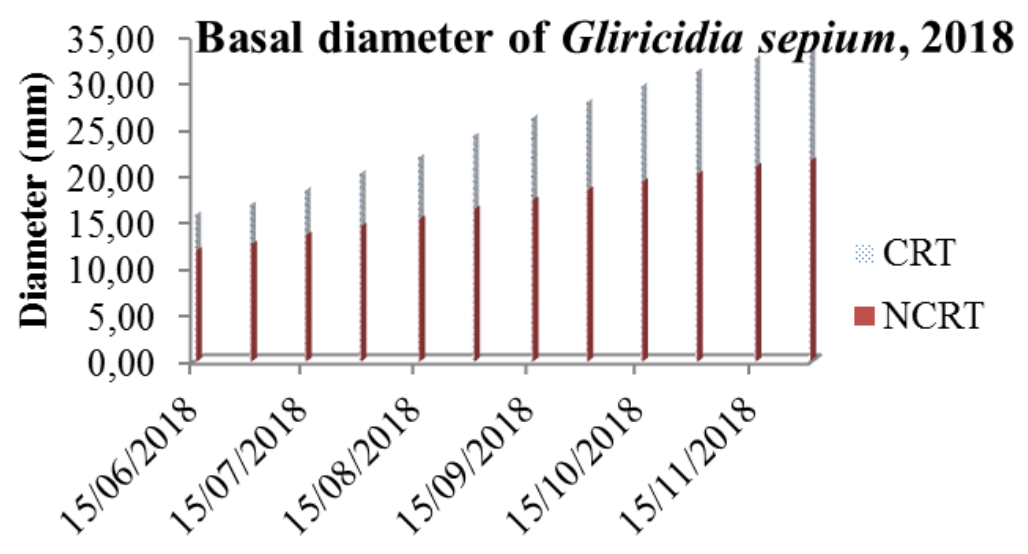

Date

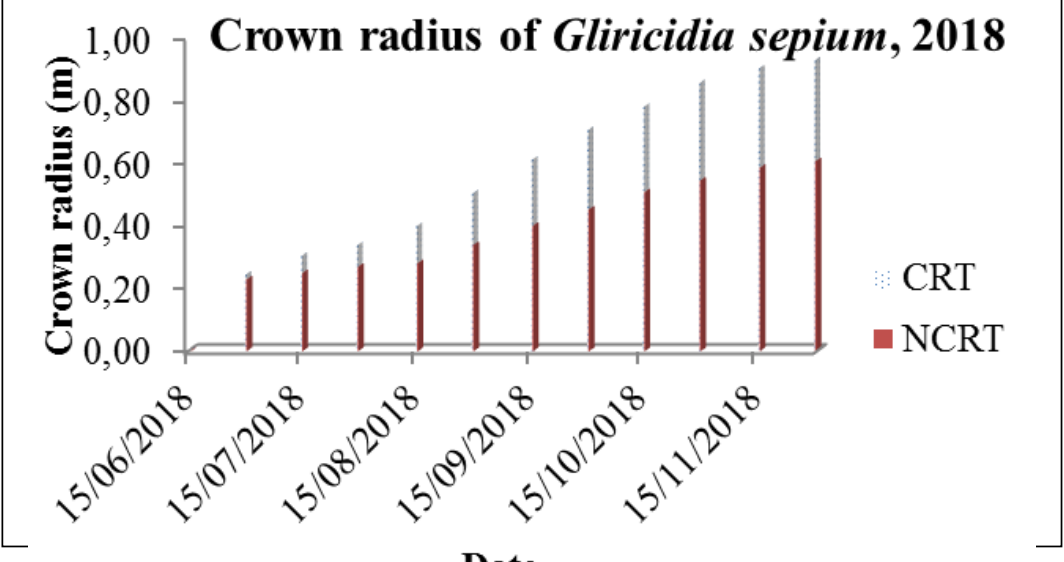

Figure 5

Date

nt at Kani and

Noumpinesso, 2018 


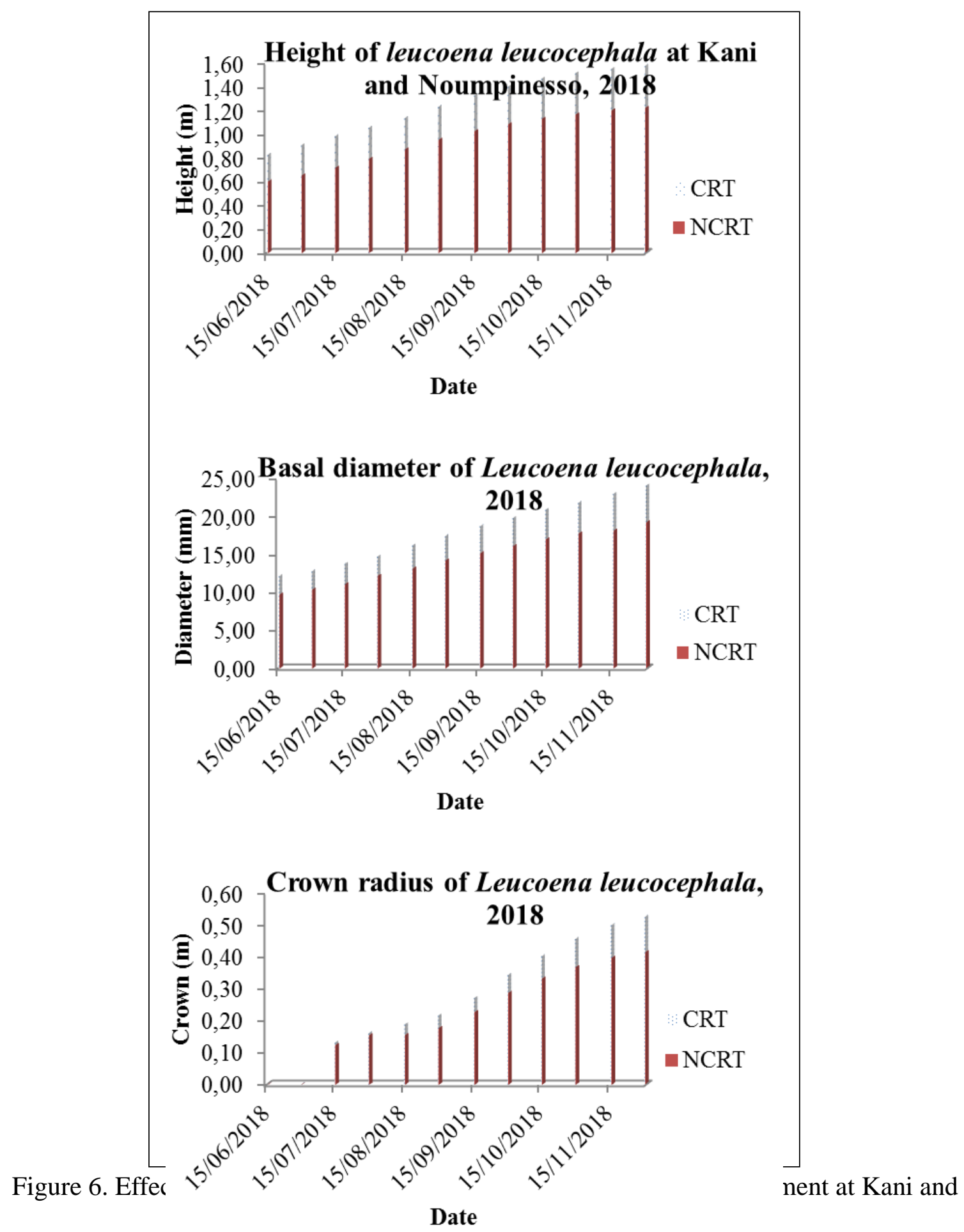

At the end of rainy season 2017, CR technology significantly $(p<0.05)$ increased growth of both Gliricidia sepium and Leucaena leucocephala. CRT application increased Gliricidia height, basal diameter, and crown by 47 and $29 \%$ respectively. It also increased Leucaena height, basal diameter, and crown size by 60 and $14 \%$ respectively. Fodder plants planted after 5 months got more than $1 \mathrm{~m}$ height and $13 \mathrm{~mm}$ diameter suggesting that Gliricidia and Leucaena are fast growing trees species, as reported by Craig and John (2006) who 


\section{Macrothink}

Journal of Agricultural Studies

ISSN 2166-0379

2021, Vol. 9, No. 2

mentioned that Gliricidia initial growth is rapid (up to $3 \mathrm{~m}$ in the first year) (Figure 7 and 8).

At the second year in 2018, fodder plants were more developed but before the rain season, animals in open grazing damaged most of these plants even they were protected with the local wooden fence. Gliricidia and Leucaena are appreciated by animals some farmers even call Gliricidia in their locale language "tourteau yiri" (tree producing cotton cake) since cotton cake is the main source of animal nutrition during the dry season when grass shortage is observed everywhere. Height, basal diameter, and crown of Gliricidia were increased with the application of CR technology by 47 and $55 \%$ respectively; and Leucaena by 29 and $29 \%$ respectively at the end of rainy season (Figure 7 and 8).

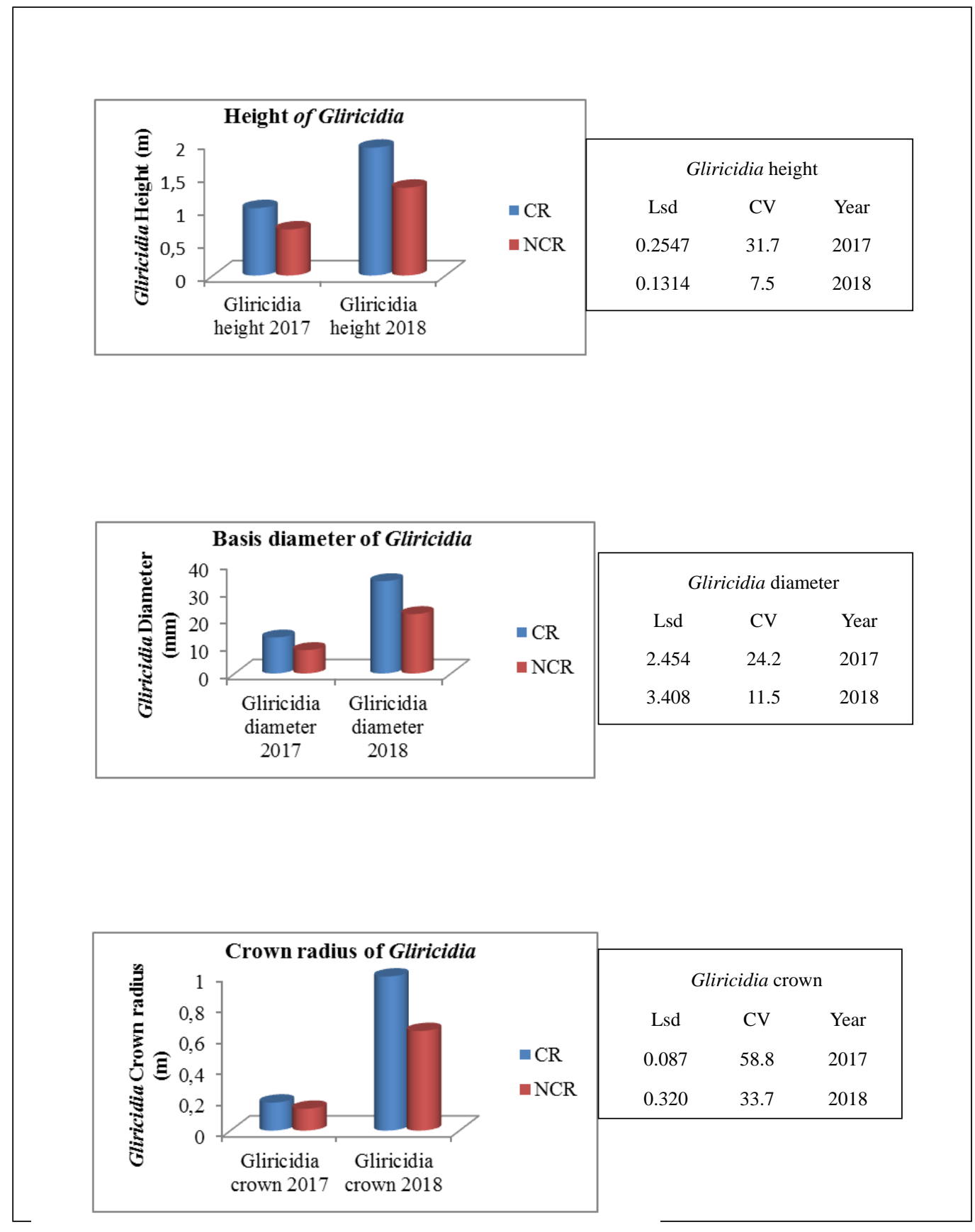


Figure 7. Height, basis diameter, and crown radius of Gliricidia sepium at Kani and Noumpinesso after rainy season in 2017 and 2018

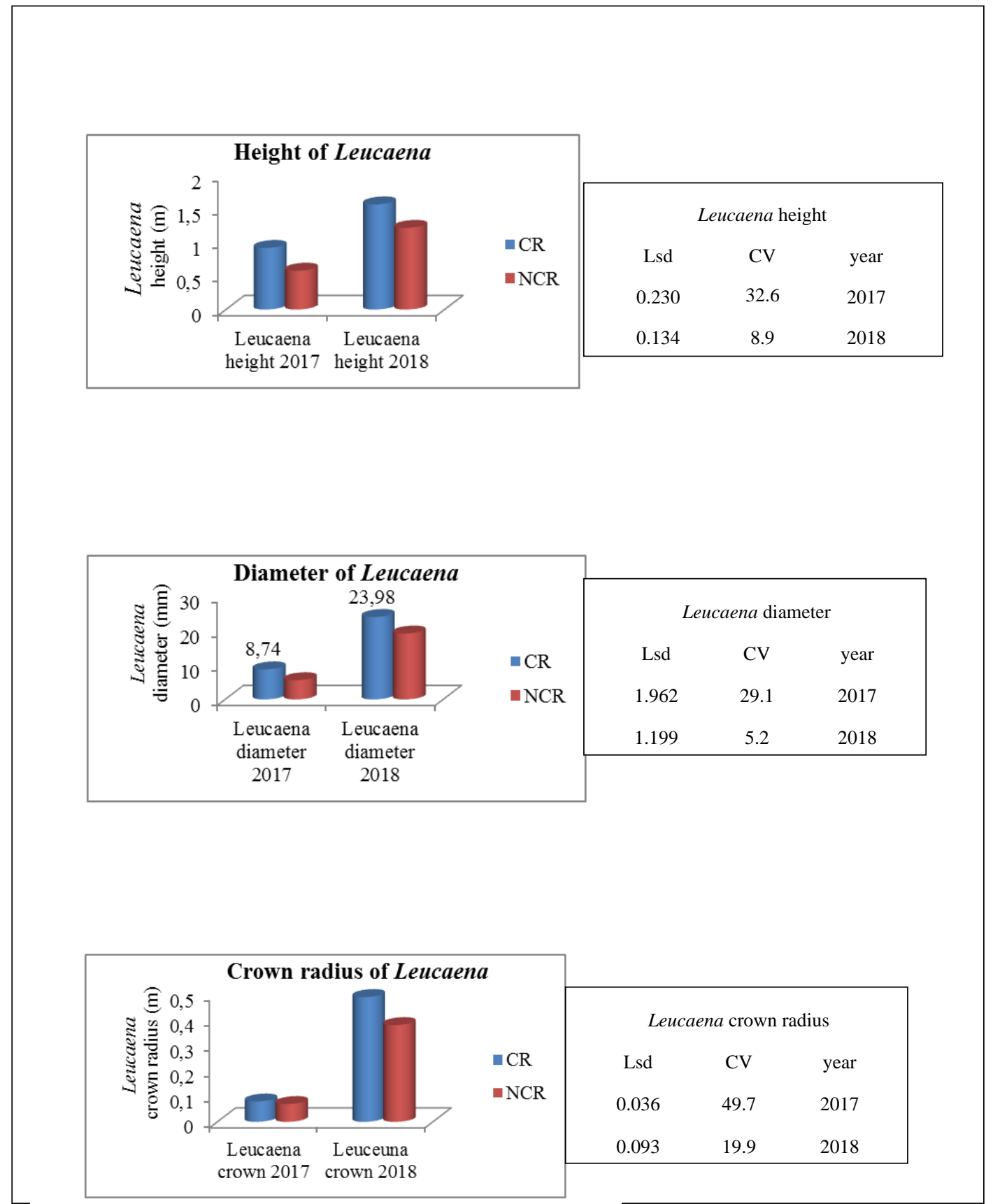

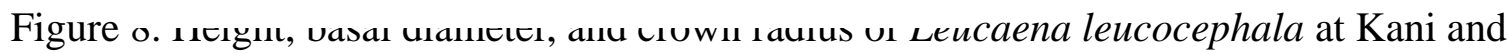
Noumpinesso after rainy season in 2017 and 2018

Figure 9 show that, biomass in CR plots was significantly $(\mathrm{p}<0.05)$ higher than those of NCR plots. The mean value of Gliricidia weight was $15.33 \mathrm{~kg} / \mathrm{plant}$ in CR plot and $12.32 \mathrm{~kg} / \mathrm{plant}$ in NCR plot. Concerning biomass of Leucaena, $10.9 \mathrm{~kg} / \mathrm{plant}$ in CR plots and $8.8 \mathrm{~kg} / \mathrm{plant}$ in NCR plots were observed. 


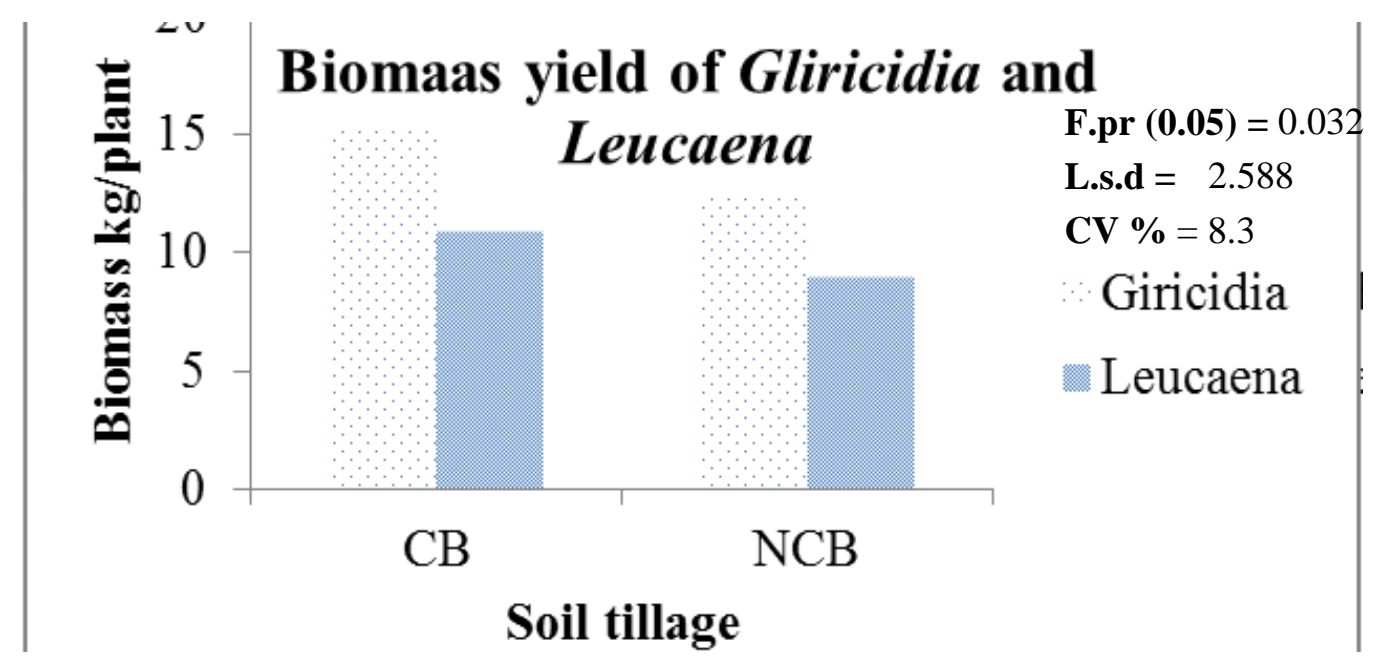

Figure 9. Effect of CRT on Gliricidia sepium and Leucaena leucocephala biomass at the second year of plantation

Gigou et al, (2000) mentioned that with the use of CR water balance was improved and soil profiles are wetter, which is favorable for trees. With a semi-arid climate, CR farming reduce soil erosion and increase water infiltration, which result in increasing growth of crops and trees associated with crops in fields. Valuable species such as shea butter trees and other ligneous within fields benefit from increased water due to the use of CR technology, which facilitates both existing tree growth and regeneration of young trees (Traore et al., 2006). Contour ridge as a result of the increased infiltration of rainfall, recharges groundwater for tree by increasing tree growth and development. Gliricidia sepium and Leucaena leucocephala are resistant to drought and valuable water conservation species. In dry season, they lose most of their leaves reducing the loss of water by transpiration. Tree growth is generally related to biomass production, CRT increased tree growth by increasing soil moisture and nutrients.

Positive correlations were observed with fodder ligneous height, biomass and basal diameter with the ten replications under CR plots and NCR plots. Tree's height and basal diameter give a high positive correlation of 0.88 . Tree's height positively correlated $(r=0.81)$ with biomass yield. Biomass yield had a high positive correlation with basal diameter growing of 0.83 . Tree's stem growth and development is related two biomass production (Figure 10). The trunk of tree acts as a representative of the amount of nutrients and water provided to develop the leaves and other parts of the plant body (June, 2019). CR increase soil moisture and reduce soil nutrient loss by erosion. Consequently, improve soil fertility and quality. Moisture increased by CR improves nutrient availability and soil porosity to increase tree's development and biomass yield. Low soil moisture reduces rot and cycling nutrient levels (Guntinas et al., 2013). 


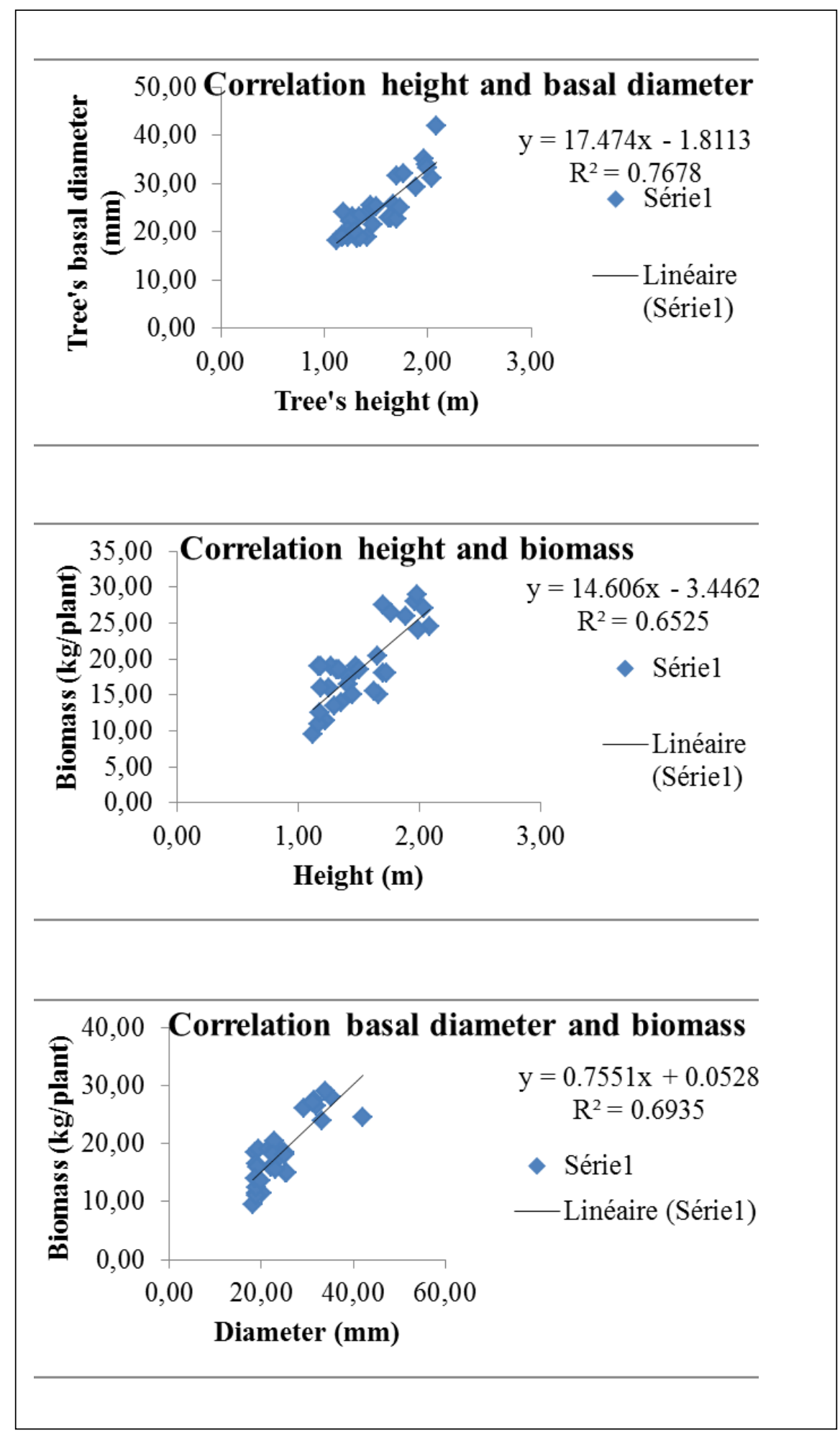

Figure 10. Effect of CR on the correlation of fodder ligneous growth and biomass such as: height and basal diameter, height and biomass and end biomass and basal diameter. 


\subsection{Effect of CR on Crops Growth and Yields}

Table 1 showed that crops height at Kani and Noumpinesso was higher in CR plots than in the NCRT one. In 2017 and 2018, CR technology increased height of sorghum by 24 and $50 \%$ and millet by 18 and $41 \%$ respectively. For maize the increase was 19 and $28 \%$, while it reached 40 and $30 \%$ for cotton, respectively. Diameter of sorghum, millet, maize, and cotton was significantly ( $\mathrm{p}<0.05)$ increased by (27 and $31 \%),(24$ and $28 \%)$, (38 and $29 \%)$, and (30 and $31 \%)$ respectively by CR technology.

Table 1: Effect of CR on crops height and diameter

\begin{tabular}{|c|c|c|c|c|c|c|c|}
\hline & Tillage & $\begin{array}{c}\text { Sorghum } \\
\text { height }(\mathrm{m})\end{array}$ & L.s.d & $\mathrm{CV} \%$ & $\begin{array}{c}\text { Sorghum diameter } \\
(\mathrm{mm})\end{array}$ & L.s.d & $\mathrm{CV} \%$ \\
\hline \multirow{2}{*}{2017} & CR & 3.06 & \multirow{2}{*}{0.521} & \multirow{2}{*}{18.9} & 18.69 & \multirow{2}{*}{3.308} & \multirow{2}{*}{19.8} \\
\hline & NCR & 2.46 & & & 14.74 & & \\
\hline \multirow{2}{*}{2018} & $\mathbf{C R}$ & 3.77 & \multirow{2}{*}{1.090} & \multirow{2}{*}{32.4} & 20.88 & \multirow{2}{*}{4.087} & \multirow{2}{*}{20.7} \\
\hline & NCR & 2.51 & & & 15.91 & & \\
\hline \multirow[b]{3}{*}{2017} & Tillage & Millet height & \multirow{2}{*}{ L.s.d } & \multirow{2}{*}{$\mathrm{CV} \%$} & Millet diameter & \multirow[b]{2}{*}{ L.s.d } & \multirow[b]{2}{*}{ CV \% } \\
\hline & & (m) & & & (mm) & & \\
\hline & CR & 3.567 & \multirow{2}{*}{0.4719} & \multirow{2}{*}{6.3} & 20.00 & \multirow[t]{2}{*}{3.129} & \multirow[t]{2}{*}{7.6} \\
\hline \multirow{3}{*}{2018} & NCK & 3.017 & & & 16.10 & & \\
\hline & CR & 3.295 & \multirow{2}{*}{0.2790} & \multirow{2}{*}{11.1} & 18.49 & \multirow{2}{*}{0.987} & \multirow{2}{*}{6.7} \\
\hline & NCR & 2.337 & & & 14.49 & & \\
\hline \multirow[b]{3}{*}{2017} & Tillage & Maize height & L.s.d & \multirow{2}{*}{$\mathrm{CV} \%$} & Maize diameter & \multirow{3}{*}{$\begin{array}{l}\text { L.s.d } \\
1.341\end{array}$} & \multirow{3}{*}{$\begin{array}{c}\text { CV \% } \\
4.7\end{array}$} \\
\hline & CR & 285 & \multirow{2}{*}{0.229} & & $\begin{array}{l}(\mathrm{mm}) \\
25.50\end{array}$ & & \\
\hline & NCR & 2.39 & & 6.8 & 18.53 & & \\
\hline \multirow{2}{*}{2018} & $\mathbf{C R}$ & 2.64 & \multirow{2}{*}{0.222} & \multirow{2}{*}{9.5} & 24.10 & \multirow{2}{*}{2.213} & \\
\hline & NCR & 2.06 & & & 18.69 & & 10.3 \\
\hline & Tillage & $\begin{array}{l}\text { Cotton height } \\
\text { (m) }\end{array}$ & L.s.d & $\mathrm{CV} \%$ & $\begin{array}{l}\text { Cotton diameter } \\
(\mathrm{mm})\end{array}$ & L.s.d & CV \% \\
\hline 2017 & CR & 1.344 & 00643 & 0 & 13.81 & & \\
\hline 2011 & NCR & 0.960 & 0.0643 & 9.2 & 10.61 & 0.150 & 10.1 \\
\hline 2018 & $\mathbf{C R}$ & 1.320 & 0.1419 & 144 & 16.84 & 1723 & 137 \\
\hline & NCR & 1.014 & 0.1419 & & 12.89 & & \\
\hline
\end{tabular}

In 2017 and 2018, CR significantly ( $<0.05$ ) increased sorghum yield by 90 and $101 \%$, millet yield by 63 and $20 \%$, respectively. The same trend was observed for maize by 87 and $63 \%$ and finally 572 and $66 \%$ were observed for cotton, respectively. CR technology was profitable with a CR greater than 2 under sorghum, millet, maize, and cotton cultivation. The highest VCR of 4.6 was noted with millet production in 2018, followed by sorghum and maize. The minimum value of 2 was observed in cotton production in 2017. Heerink (2005) stated that technically, a VCR greater than 2 means the treatment is profitable. The results of this study agree with this statement. At Kani and Noumpinesso the recommended doses of fertilizer on cotton and maize were higher than those of millet and sorghum. Most of farmers don't apply fertilizer in millet and sorghum but they planted them in rotation with cotton or maize, to benefit from the residual effect of fertilizers in crops rotation system. CR significantly increased sorghum, millet, maize, and cotton) straw yields in the two seasons of 
research by (39 and $88 \%),(92$ and $80 \%),(55$ and $71 \%)$, and (81 and $66 \%)$ respectively (Table 2).

Table 2: Effect of CR on crops grain yields and farmer's income

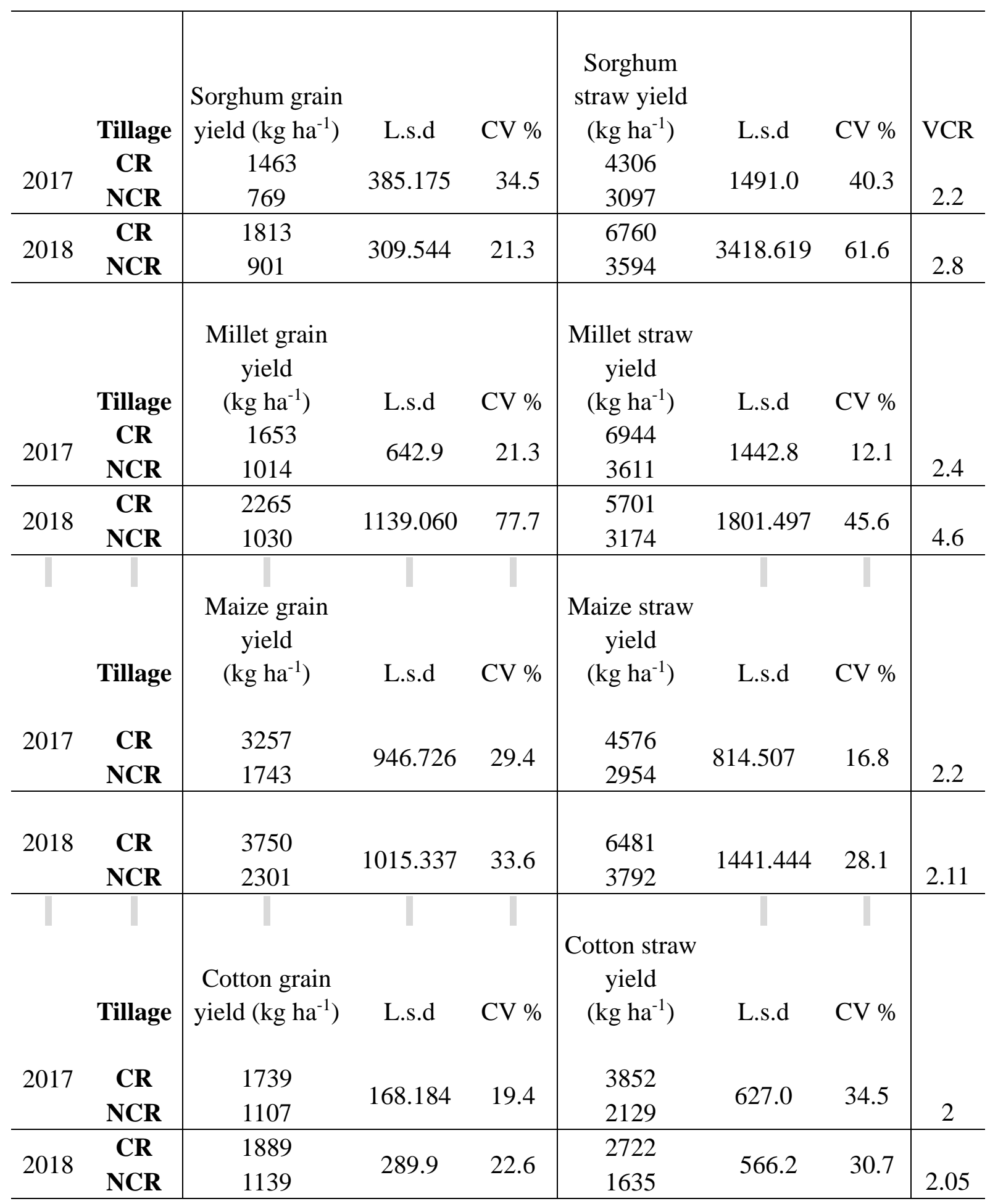

In 2017 like 2018, CR technology significantly ( $<$ < 0.05) increased sorghum, millet, maize, and cotton growth and yield. Use of CR technology is an efficacious technology in reducing erosion and consequently maintaining nutrient availability for crop. This technology also 


\section{Macrothink

improves soil moisture for crop and is favorable for organic matter decomposition and improves nutrient availability for crop and trees. At the same area in 2017, maize average grain yield was $87 \%$ higher in CR plots than in NCR plots. For sustaining soil productivity, CR technology is advocated as a better soil and water conservation technique than the NCR one (Traoré and Birhanu, 2020). These findings document increased soil water content resulting in increased crop yields. Yields were increased by $50 \%$ for millet, sorghum, and maize (Gigou et al., 2006). Traore et al. (2004) reported that the effects of CR increased millet yields by $27 \%$ (1998), $2 \%$ (1999) and $60 \%$ in 2000 in Mali. The improvement observed in grain yield is attributable to moisture conservation capacity of the CR technology. Soil moisture conservation is vital for smallholder cropping systems as reported by several authors (Falkenmark et al., 2001; Irshad et al., 2007; Birhanu et al., 2020; Traore et al., 2020,). Moisture stored in soil profile, supplied water to crop at the end of rainy season when plants are flowering and filling their grains, leading to yield increase. Our finding is in agreement with those of Li et al., (2008) and Khlifi (2008), who reported that CR increased soil nutrient and available soil moisture for crop root uptake and improved crop growth and yields than NCR.

\subsection{Effect of Fodder Plants on Soil Moisture}

In 2017 results showed that maximum soil moisture was obtained in August at $100 \mathrm{~cm}$ soil deep when the rain was frequent. Maximum soil moisture of $53.3 \%$ under tree's crown and $41.3 \%$ outside tree's crown were found in CR plot. In NCR plot, maximum moisture of $47.2 \%$ under tree's crown and $43.1 \%$ outside tree's crown were measured. Soil water content was always higher under than outside tree crown in both CR and NCR plots. The difference was high in CR plot compared to NCR plot. At 0-100 cm deep soil moisture was increased by tree's shade by $30 \%$ in CR plot and by $16 \%$ in NCRT plot. Soil water content was greater in 40-100 $\mathrm{cm}$ deep than the superficial layer 0-40 $\mathrm{cm}$ from the middle at the end of rainy season 2017 (Figure 11). 

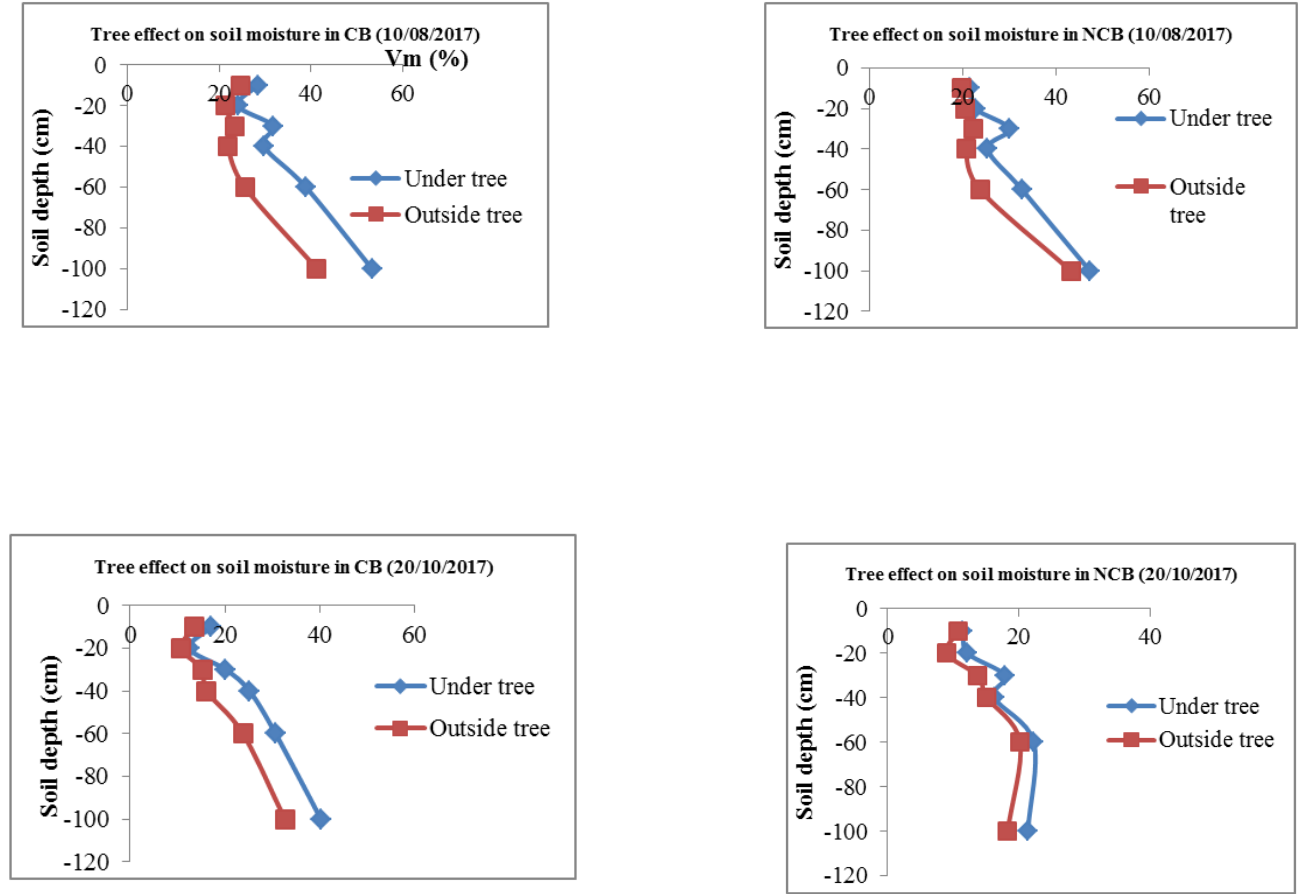

Figure 11. Vertical distribution of soil moisture under and outside fodder plant in CB and NCR plots, 2017

In 2018 also, trend like that of 2017 was observed. In CR plot like in NCR plot the maximum soil moisture was obtained in August. Maximum soil water content of $40.6 \%$ under tree crown and $32.5 \%$ outside tree crown was obtained at $60 \mathrm{~cm}$ deep in CR plot. For NCR plot the maximum soil moisture was measured at $100 \mathrm{~cm}$ soil deep in, which $33.5 \%$ under tree crown and $32.8 \%$ outside tree crown. At 2018 rainy season soil water content was always higher under than outside tree crown in both CR and NCR plots, but the difference was higher with CR plot.

Soil moisture was increased by tree shade in CRT plot by $19 \%$ in CR plot and $12 \%$ in NCR plot in August. Soil water content was greater in 40-100 cm deep than the superficial layer 0-40 $\mathrm{cm}$ from the beginning at the end of rainy season 2017 (Figure 12). 

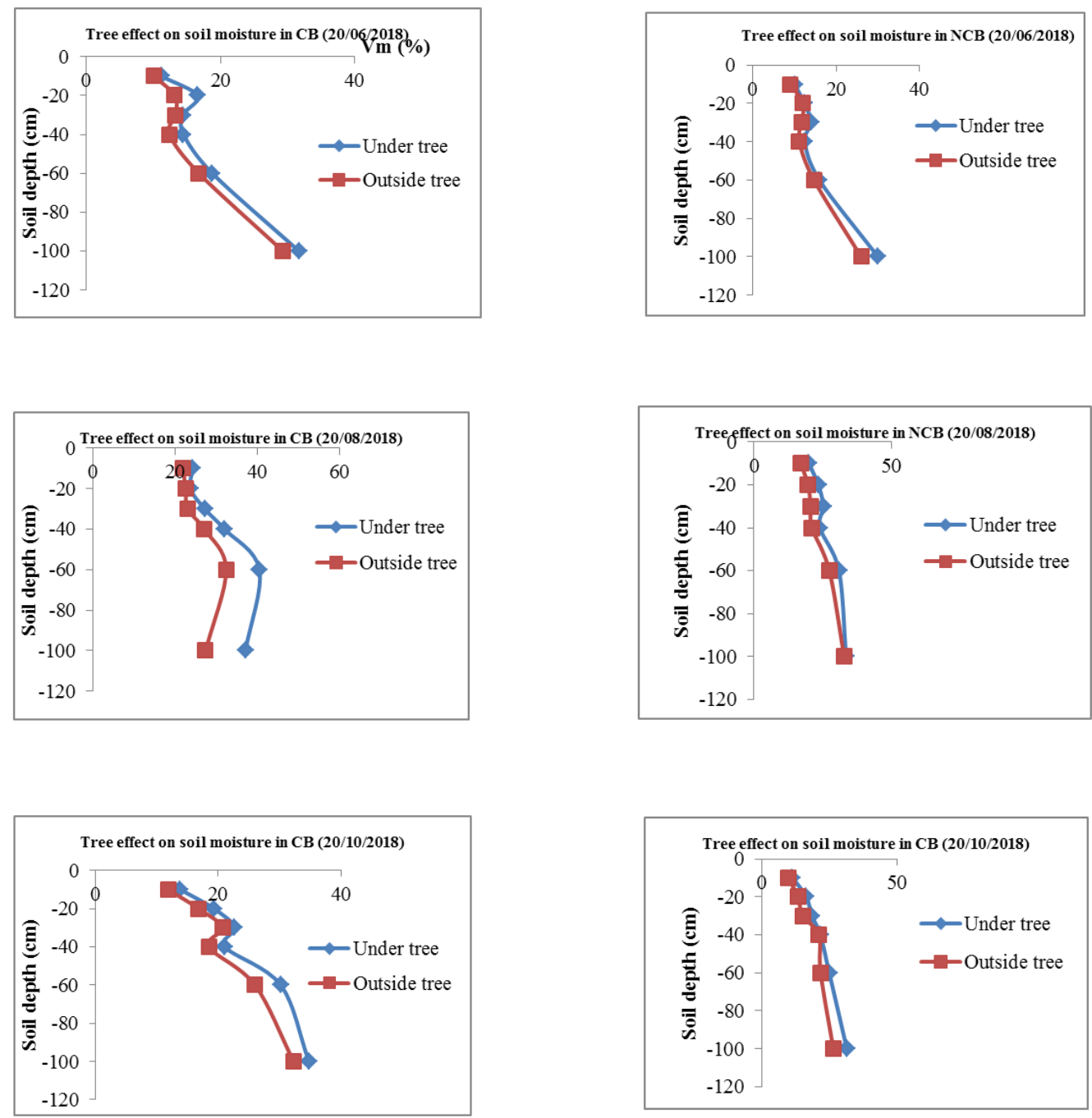

Figure 12. Vertical distribution of soil moisture under and outside fodder plant in CR and NCR plots, 2018

At Kani, in 2017 and 2018 cropping season, soil moisture was always higher under than outside the tree crown and the difference was higher in CR fields than NCR fields. This advantage was observed because fodder trees were planted on the crest of the permanent ridge, which captured a maximum quantity of runoff water. Tree root and crown contributed to store water in soil. Improving soil's structure includes increasing its fertility and helps prevent soil from erosion. The penetration of tree roots improves soil structure by improving aeration and drainage; probing root growth breaks up the soil, which creates spaces for storing air and water (Victoria, 2018). Tree roots improve drainage in which each root acts as an underground water channel to facilitate water penetration to the soil (Victoria, 2018). Similarly, Kablan et al. (2008) noted that CR increased soil moisture in areas occupy by plant roots by $16 \%$ to $64 \%$ compared to NCR plots. Our results are also in agreement with those of Doumbia et al. (2012) who mentioned $17 \%$ water storage in CR plots in the $80-160 \mathrm{~cm}$ 
profile horizons and $12.7 \%$ in the first $80 \mathrm{~cm}$. At the end of the rainy season, soil moisture was at least $25 \%$ explaining a real water supply potential for the trees of the park as reported by Kablan et al. (2008) in assessment of the effects of CR on soil water dynamic in Siguidolo and Fansirakoro. Less moisture was observed at the soil upper layers in opposition of the deepest ones. This is due to evapotranspiration caused by sunlight and wind which decrease moisture. However, soil type (texture and structure) and infiltration rate acted as determining variables for increasing soil moisture deep in the soil profile. Soil is better wet in August, because rain was heavier and more frequent at this period.

\section{Conclusion}

The study had shown that CR technology increased fodder plant growth and development. In fact, during 2017 and 2018 growing season, CR technology significantly ( $<<0.05$ ) increased height, diameter, and crown of Gliricidia sepium and Leucaena leucocephala). Similarlly, growth (height, diameter) and yields, (grain and straw) of crops (sorghum, millet, maize, and cotton) were significantly ( $\mathrm{p}<0.05$ ) increased by the use of CR. Application of CR was profitable in both year 2017 and 2018 under sorghum, millet, maize, and cotton production. Among these crops, millet and sorghum production was more profitable and give the best VCR of 2.8 and 4.6 respectively. Soil moisture was greater under crown of Gliricidia sepium and Leucaena leucocephala than out of their crown and the difference is significant $(\mathrm{p}=0.5)$. In fact, in August 2017, fodder plants improved soil moisture at $1 \mathrm{~m}$ depth by $30 \%$ in CR plot and by $20 \%$ in NCR which is farmer's practice. In August 2018, the increase was $20 \%$ in CR plot and $13 \%$ in farmer's practices.

\section{Acknowledgments}

This work was funded by Africa Research in Sustainable Intensification for the Next Generation (Africa RISING). I also thank my research institute (Rural Institute Economy, IER) for supporting all step of that work.

\section{References}

Birhanu, B. Z., Traore, K., Gumma, M. K., Badolo, F., Tabo, R., \& Whitbread, A. M. (2018). A Watershed Approach to Managing Rainfed Agriculture in the Semiarid Region of Southern Mali: Integrated Research on Water and Land Use. Environment, Development and Sustainability, 21, 2459-2485. https://doi.org/10.1007/s10668-018-0144-9

Birhanu, B. Z., Traoré, K., Sanogo, K., Tabo, R., Fischer, G., \& Whitbread, A. M. (2020). Contour bunding technology-evidence and experience in the semiarid region of southern Mali. Renewable Agriculture and Food Systems, 1-9. https://doi.org/10.1017/ S1742170519000450

Craig, R. E., \& John, K. F. (2006). Species Profiles for Pacific Island Agroforestry www.traditionaltree.org. Gliricidia sepium (gliricidia) Fabaceae (legume family). gliricidia, Mexican lilac, mother of cocoa, Nicaraguan cacao shade, quick stick, St. Vincent plum, tree of iron (Eng-lish); immortelle, lilas étranger (French); madre de cacao (French, Spanish); rechesengel (Palau).

Ver.

2.I. https://www.agroforestry.org/books/3-traditional-trees-of-pacific-islands 
De Baets N., S. Gariépy \& A. Vézina. (2007). Portrait of agroforestry in Quebec. Executive summary. (pdf) AAFC \# 10241ECatalog \# A22-418/2007-1E-PDFISBN \# 978-0-662-45217-1

Doumbia Mamadou D., Kone, M., Traore, S., Samake, O., Sissoko, P., Vara Prasad, P. V., Dalton, T., \& Jesse, N. (2012). Improving Soil Quality and Crop Productivity Through Conservation Agriculture in Mali, Western Africa. (1) Institut d'Economie Rurale, Bamako, Mali: 42-5

Falkenmark, M., Fox, P., Persson, G., \& Rockström, J. (2001). Water harvesting for upgrading of rainfed agriculture - Problem analysis and research Needs. SIWI Report No11

Gigou, J., Traoré, K. B., Coulibaly, H., Vaksmannl, M., \& Kouressi, M. (2000). Aménagement en courbes de niveau et rendements des cultures en région Mali-sud: CIRAD, BP1813, Bamako, Mali: IER-Laboratoire Sol-Eau-Plante, BP43 8, Bamako, Mali. 19-391-404 pdf

Gigou, J., Traoré, K., Giraudy, F., Coulibaly, H., Sogoba, B., \& Doumbia, M. (2006). Aménagement paysan des terres et réduction du ruissellement dans les savanes africaines. In Agricultures, 15(1), 116-122.

Guntinas, M. E., Gil-Sotres, F., Leiros, M. C., \& Trasar-Cepeda, C. (2013). Sensitivity of soil respiration to moisture and temperature. J. Soil Sci. Plant Nutr., 13, 445-461. https://doi.org/10.4067/S0718-95162013005000035

Heerink, N. (2005). Soil fertility decline and economic policy reform in Sub Saharan. Land use policy, 22, 67-74. https://doi.org/10.1016/j.landusepol.2003.08.002

Herbold, N. H. (2003). In Field Guide to Appropriate Technology. Components of an agroforestry system

Irshad, M., Inoue, M., Ashraf, M., \& Al-Busaidi, A. (2007). The management options of water for the development of agriculture in dry areas. Journal of Applied Sciences, 7(11), 1551-1557. https://doi.org/10.3923/jas.2007.1551.1557

Jose, S. (2009). Agroforestry for ecosystem services and environmental benefits: an overview. Agrofor Syst. 76, 1-10. https://doi.org/10.1007/s10457-009-9229-7

Kablan, R., Yost, R. S., Brannan, K., Doumbia, M. D., Traoré, K., Yoroté, A., ... Sissoko, M. (2008). Aménagement en courbes de niveau," Increasing Rainfall Capture, Storage, and Drainage in Soils of Mali, Arid Land Research and Management, 22(1), 62-80. https://doi.org/10.1080/15324980701784191

Khlifi, S. (2008). Contribution à l'étude d'impact des aménagements antiérosifs sur la fertilite des sols en Tunisie Centrale. Agrosolutions, 19(2).

Kouyaté Z, Franzluebbers K, Juo ASR, Hossner LR (2000) Tillage, crop residue, legume rotation, and green manure effects on sorghum and millet yields in the semiarid tropics of Mali. Plant Soil, 225, 141-151. 
Li, Y. X., Tullberg, J. N., Freebairn, D. M., Mclaughlin, N. B., \& Li, H. W. (2008). Effects of tillage and traffic on crop production in dryland cropping systems: II. Long-term simulation of crop production using PERFECT model. Soil and Tillage Research, 100(1-2), 25-33. https://doi.org/10.1016/j.still.2008.04.005

Ortolani, G. (2017). Agroforestry: An increasingly popular solution for a hot, hungry world Mongabay Series: Global Agroforestry

Palsaniya D. R., M. A. Khan, R. K. Tewari and C. K. Bajpai. (2012). Tree-crop interactions in Psidium guajava based agrihorticulture system. Range Mgmt. \& Agroforestry, 33(1), 32-36, 2012. ISSN 0971-2070

Sun, J., Wang, M. T., Lyu, M., Niklas, Karl J., Zhong, Q. L., Li, M., \& Cheng, D. L. (2019). Stem Diameter (and Not Length) Limits Twig Leaf Biomass. https://doi.org/10.3389/fpls.2019.00185

Traoré, K. B., Gigou, J. S., Coulibaly, H., \& Doumbia, M. D. (2004). Contoured Ridge-tillage Increases Cereal Yields and Carbon Sequestration. ISCO 2004- 13th International Soil Conservation Organization Conference - Brisbane, July 2004; Conserving Soil and Water for Society: Sharing Solutions

Traoré, K. B., McCarthy, G., Gigou, J. S., Doumbia, M. D., Bagayoko, A., Yost, R. S., ... Kablan Cirad-Tera, R. A. (2006). Aménagement en courbes de niveau et conservation du carbone.

Traoré, K. B., McCarthy, G., Gigou, J. S., Doumbia, M. D., Bagayoko, A., Yost, R. S., ... Kablan, R. A. (2002). Aménagement en courbes de niveau et conservation du carbone, Paper presented at the Colloque International, Gestion de la biomasse, ruissellement, érosion et séquestration du carbone, 24-28 septembre, 2002, Montpellier, France

Traoré, K., \& Zemadim, B. (2020). Soil erosion control and moisture conservation using contour ridge tillage in Bougouni and Koutiala, southern Mali. https://doi.org/10.4236/jep.2019.1010079

Victoria, W. (2018). How Tree Roots Affect Soil. Colorado State University Extension: Healthy Roots and Healthy Trees

\section{Copyright Disclaimer}

Copyright for this article is retained by the author(s), with first publication rights granted to the journal.

This is an open-access article distributed under the terms and conditions of the Creative Commons Attribution license (http://creativecommons.org/licenses/by/4.0/). 